\title{
Exploratory Study of Service Quality, Corporate Image, and Customer Loyalty in Restaurants in Ghana
}

\author{
Edward Markwei Martey, Richard Amoasi, Prince Aboagye \\ Faculty of Business and Management Studies Koforidua Technical University \\ Faculty of Business and Management Studies Koforidua Technical University \\ Marketing Department Koforidua Technical University
}

\begin{abstract}
The aim of the study is to identify the effect of Service Quality and Corporate Image on Customer's Loyalty .Questionnaires were distributed to collect responses from restaurant users in the Greater Accra region of Ghana. Descriptive statistics and correlation analysis were used to analyze the data and draw the conclusions. It was revealed that service quality and corporate image have strong positive association with customer's loyalty. The study suggested that managers of restaurants provide needed logistics to aid frontline staff to avoid delays in meeting customer demands. This will lead to high level of customer retention, loyalty, high market share and profitability.
\end{abstract}

Keywords: Corporate Image; Customers; Loyalty; Service Quality; Retention

\section{Introduction}

The study focused on the contribution of service quality and corporate image on customer satisfaction and loyalty in the restaurant industry in Ghana. In today's competitive market, where restaurants provide almost similar services, managers are forced to differentiate their services through the use of corporate image and service quality (Ball et al. 2006). Presently, customer's expectation for quality service and after-sale service are high due to stiff competitions and managers interested at keeping customer who patronized their services (Nguyen \& Leblanc, 2001)

According to Parasuraman et al. (1988) service quality is experienced through evaluation of customers' expectations against perceived performance of services. Besides, (Raj, 1985) advised managers to rely on corporate image and service qualityto attract and maintain loyal customers.

Several researchers have spent time to examine the effect of service quality on customers' purchase intentions (Eggert\&Ulaga, 2002). Previous studies revealed a positive relationship between service quality and perceived value which creates customers loyalty (Bauer et al., 2006). Turel and Serenko (2006) and Wang et al. (2004) premeditated mobile services in Canada and China respectively and found positive relationship between service quality, corporate image and customer loyalty. Similarly, Eggert and Ulaga, (2002) established a positive relationship between these variables. Probing airline services,Ostrowski et al. (1993) explained that customer's positive experiences lead to positive image. (Yi \& Gong, 2008)

Though much has been researched in the developed country on the topic, very little has been done in the hospitality industry in developing countries such as Ghana. The study is therefore intended to fill the gap in literature by investigating the contribution of corporate image and service quality on customer loyalty in the restaurant industry in Ghana.

Literature Review.

Service quality and customer loyalty 
Service quality influences the ability of an organization to satisfy customers' needs, according to their expectation level (Yoo\& Park, 2007). Service quality is connected with customers' attitudes towards service supplier and their objective to stay with a service provider (Bellet al. 2005).According to Lai et al., (2009) service quality is a key driver of loyalty. Besides, Gruen et al., (2006) established a positive relationship between word-of-mouth communication and customer loyalty. Study also found positive correlation between service quality and customer satisfaction (Cronin et al., 2000), which leads to customer loyalty (Lai et al., 2009). This led to the first hypothesis; H1: is there a relationship between service quality and customer loyalty

\section{Service quality and customer satisfaction}

Although Bolton and Drew (1991) and Carman (1990) propose that satisfaction impacts on service quality, Anderson and Sullivan (1993), Cronin and Taylor (1992), and Woodside et at. (1989) provide empirical evidence in support of service quality as an antecedent to customer satisfaction, which exerts a stronger influence on purchase intentions than satisfaction.

This led to the second hypothesis H2: is there association between service quality and customer satisfaction

\section{Corporate image and customer loyalty}

Ostrowski et al. (1993) examine the airline industry and argue that positive experience over time ultimately leads to positive image. Corporate image relate to customer retention likelihood (Ball et al. 200). This led to the third hypothesis H3: is there a relationship between corporate image and customer loyalty

\section{Perceived value and customer satisfaction}

Lin and Wang (2006) found a positive relationship between perceived value and customer satisfaction. Cronin et al. (2000) also found direct relationship of perceived value with word-of-mouth communication and repurchase intentions (Cronin et al. 2000). Wang et al. (2004) and Lin and Wang (2006) also supported this result. This led to the fourth hypothesis H4: is there a relationship between perceived value and customer satisfaction

\section{Service quality and perceived value}

The term perceived value can be defined as "the benefits or outcome that customers receive in relation to total costs (which include other associated cost plus the price of the paid with the purchase) or the consumers' overall evaluation of what is received relative to what is given"(Zeithaml, 1988).Bauer et al., (2006) pointed out a positive relationship among service quality and perceived value which causes loyalty among the customers. This led to the fifth hypothesisH5: is there a relationship between service qualities and perceive value.

\section{Methods}

Qualitative and quantitative methods were used in the empirical segment of the study (Terre Blanche, Durrheim\& Painter 2006). The researcher used purposive technique in selecting the various restaurant whiles convenience sampling was employed on users of identified restaurants. This is due to the difficulty in determining the specific list of customers who patronized restaurants in Ghana. The target population was restaurants users who were within the ages of 18 and 60 years in the Greater Accra region of Ghana, 351 of 500 respondents returned their questionnaires.

\section{Data collection}

Data were collected through the use of structured questionnaire. The questionnaire was divided into six sections. Section A elicited general and biographical information about respondents. Section B elicited information on service quality. Section C sought information of corporate image. The questions in Section $\mathrm{D}$ elicited information on customer loyalty. The section E sought information on customer satisfaction. The questions in Section F elicited information on perceived values .Likert scales anchored by strongly disagree (1) and strongly agree (5) were used. 


\section{Data analysis}

The data was collected and entered into a computer using SPSS. The following statistics were used: Pearson correlation ( $r$ ) to determine the relationship between service quality and corporate image on customer loyalty. According to Sekaran the correlation between two variables is considered a perfect positive correlation when it is close to +1 , or perfect negative correlation when it close to -1 . "Pearson correlation only shows the strength and direction of relationship (Sekaran,2003).

\section{Result and Discussion}

Following the guidelines indicated in the research methodology section, the researchers collected data in 2016.

\section{Demographic information}

Table 1; Demographic information

\begin{tabular}{|c|l|l|}
\multicolumn{1}{c|}{ Variables } & \multicolumn{1}{c|}{ Prequency } & \\
\hline Gender & 148 & 42.2 \\
\hline Female & 203 & 57.8 \\
\hline Male & 351 & 100.0 \\
Total &
\end{tabular}

\begin{tabular}{|c|l|l|}
\hline \multicolumn{1}{|c|}{ Age-28-39 } & 69 & 19.7 \\
\hline $40-59$ & 116 & 33.0 \\
\hline Total & 166 & 47.3 \\
\hline Restaurants & 351 & 100 \\
& & \\
SFC & & \\
KFC & 67 & 19.1 \\
Chicken Republic & 64 & 18.2 \\
Korean Restaurants & 66 & 18.8 \\
Frankie's Restaurants & 53 & 28.8 \\
Total & 351 & 15.1 \\
\hline No. of visits & & 100 \\
\hline Below 5 times & 163 & \\
\hline Between 6 to 10 & 156 & 46.5 \\
\hline More than 11 & 32 & 44.4 \\
\hline Total & 351 & 9.1 \\
\hline
\end{tabular}

\section{Survey results, 2016}

A detailed demographic analysis of respondents is presented in Table 1. Questionnaires were distributed to clients who had visited restaurants at least once in the past year. 351 completed questionnaires were collected from the respondents out of 500 questionnaires distribute. Among the sample data: $57.8 \%$ respondents were males. This means men visit restaurants than women. Also, $47.3 \%$ were in the $40-59$ age groups, which is the modal age. Besides, Korean restaurant is the highest patronized restaurants.

Table 2.Supporting literature for measurement scales. 


\section{(Source: field work, 2016)}

\begin{tabular}{|l|l|}
\hline Constructs & scales \\
\hline Service quality (SQ) & {$[41,55]$} \\
\hline Corporate image (CI) & {$[37,46]$} \\
\hline Perceived Value (PV) & {$[50,57]$} \\
\hline Customer loyalty (CL) & {$[44,58]$} \\
\hline Customer satisfaction(CS) & {$[41,59]$} \\
\hline
\end{tabular}

All of the measurement scales used, as indicated in Table 2, were based on previous research. Assuring the validity and reliability of the measures required supporting literature to validate the scales which were used in the research constructs. The construct was measured using the scales and indices included in the work of (Nguyen \& Leblanc and 2001 Lin and Wang 2006) used the following variables to determine the construct of the study were measurement scales adapted from previous studies.

Table 3. Values of Cronbach's alpha for the research dimension

(Source: field work, 2016)

\begin{tabular}{|l|l|}
\hline Constructs & Value \\
\hline Service quality (SQ) & 0,730 \\
\hline Corporate image (CI) & 0,743 \\
\hline Perceived Value (PV) & 0,723 \\
\hline Customer loyalty (CL) & 0.752 \\
\hline Customer satisfaction(CS) & 0.741 \\
\hline
\end{tabular}

A reliability test was carried out using Cronbach's alpha, which measures the internal consistency of a construct. The recommended minimum acceptable limit of reliability measure, as reported by (Sekaran, 2003 ) is 0.60 . As shown in Table 3 , all the constructs passed the reliability test.

Table 4. Descending means of theconstructs

\begin{tabular}{|l|l|l|}
\hline Dimension & Mean & Standard deviation \\
\hline Service quality (SQ) & 4.20 & 0,700 \\
\hline Corporate image (CI) & 4.132 & 0,717 \\
\hline Perceived Value (PV) & 4.031 & 0,728 \\
\hline Customer loyalty (CL) & 4.952 & 0.743 \\
\hline Customer satisfaction(C) & 4.032 & 0.720 \\
\hline
\end{tabular}

(Source: field work, 2015)

The result shown in Table 4 indicates frequency and descriptive statistics used to determine the relative importance of each of the dimension. The constructs shown in Table 4 have a meanabove 4 . Therefore it concludes that all of constructs are of significant importance to the study.

Table 5.Skewness and Kurtosis for research constructs. Variable

\begin{tabular}{|l|l|l|}
\hline Construct & Skewness & Kurtosis \\
\hline Service quality (SQ) & $\mathbf{- 0 . 3 4}$ & $\mathbf{- 0 . 6 2}$ \\
\hline Corporate image (CI) & $\mathbf{- 0 . 3 7}$ & $\mathbf{- 0 . 5 3}$ \\
\hline Perceived Value (PV) & $\mathbf{- 0 . 2 5}$ & $\mathbf{- 0 . 6 5}$ \\
\hline Customer loyalty (CL) & $\mathbf{- 0 . 5 4}$ & $\mathbf{- 0 . 7 5}$ \\
\hline Customer satisfaction(C) & $\mathbf{- 0 . 2 1}$ & $\mathbf{- 0 . 6 8}$ \\
\hline
\end{tabular}

\section{(Source: field work, 2016)}

From Table 5, Kurtosis and Skewness values were used to check the normality of each variable used in the research. Skewness values larger than $(+1)$ or smaller than $(-1)$, as suggested by Hair et al (2003) indicate a substantially skewed distribution. Besides Hair et al (2005) added that a curve is too peaked when the 
Kurtosis exceeds $(+3)$ and is too flat when it is below $(-3)$. This means Skewness values within the range of $(-1)$ to $(+1)$ and Kurtosis values within the range of $(-3)$ to $(+3)$ indicate an acceptable range. As shown in Table 5, the values of Skewness and Kurtosis for each variable indicate that the research constructs fell within the acceptable range.

\section{Correlations Analysis}

Table 7; Correlations analysis

\begin{tabular}{|l|l|l|l|l|l|}
\hline & SQ & CI & PV & CL & CS \\
\hline SQ & $\mathbf{1}$ & $013(.703)$ & $0.18(* *) .000$ & $0.02(.674)$ & $0.12(* *) .002$ \\
\hline CI & $0.13(.703)$ & $\mathbf{1}$ & $0.99(*) .026$ & $0.01(.707)$ & $145(* *) .001$ \\
\hline PV & $0.18(* *) .000$ & $0.99(*) .026$ & $\mathbf{1}$ & $0.120(.612)$ & $0.01(.118)$ \\
\hline CL & $0.02(.674)$ & $0.01(.707)$ & $0.120(.612)$ & $\mathbf{1}$ & $0.42(.621)$ \\
\hline CS & $0.12(* *) .002$ & $145(* *) .001$ & $0.01(.118)$ & $0.42(.621)$ & $\mathbf{1}$ \\
\hline
\end{tabular}

** Correlation is significant at the 0.01 level (2-tailed).

(Source: field work, 2016)

\section{Relationship between service quality and customer loyalty}

The Pearson correlation in Table 7 shows that there is a positive and significant relationship between responsiveness and customer satisfaction $\mathrm{r}=0.002, \mathrm{p}<.01$ ). Therefore, the research hypothesis 1 is accepted and proven to be true. This means an increase in service quality level would increase customer loyalty.

\section{Relationship between service quality and customer satisfaction}

The Pearson correlation in Table 7 shows that there is a positive and significant relationship between empathy and customer satisfaction $r=0.002, p<.01$ ). Therefore, the research hypothesis 2 is accepted and proven to be true. This means an increase service quality would lead to increase in customer satisfaction.

\section{Relationship between corporate image and customer loyalty}

The Pearson correlation in Table 7 shows that there is a positive and significant relationship between reliability and customer satisfaction $r=0.001, \mathrm{p}<.01$ ). Therefore, the research hypothesis 3 is accepted and proven to be true. That means any increase in corporate image level will be followed by increase in customer loyalty.

\section{Relationship between perceived value and customer satisfaction}

The Pearson correlation in Table 3 shows that there is a positive and significant relationship between assurance and customer satisfaction $r=0.001, p<.01$ ). Therefore, the research hypothesis 4 is accepted and proven to be true. This means an increase in the level of perceived value will be followed with increase in customer satisfaction.

\section{Relationship between service quality and perceived value}

The Pearson correlation in Table 3 shows that there is a positive and significant relationship between tangibility and customer satisfaction $r=0.01, p<.01$ ). Therefore, the research hypothesis 5 is accepted and proven to be true. This means an increase in service quality would lead to an increase in perceive

\section{Discussions}

The study examines the relationship between service quality, corporate image and customer loyalty among restaurants customers in Ghana. Investigation conducted revealed that all the five hypotheses formulated after a reviewed literature are accepted. The findings are consistent with Eskildsen et al. (2004), they stated that, service quality, creates effective communication with customers and potential customers. The most important factor in developing and maintaining loyalty is corporate image (Bauer et al., 2006)

Johnson et al., (2001) argued that corporate image is considered as attitude which is directly associated with customer satisfaction and loyalty because of its functional components, the findings revealed a strong correlation between service quality and loyalty. The finding is also consistent with (Cook 2004) and Martey 
and Frempong(2014), argued that service quality is indeed a significant predictor of customer satisfaction. A study conducted by Bauer et al., (2006) also confirmed a positive relationship among service quality and perceived value which leads to loyalty among the customers.

\section{Conclusions}

The results showed that service quality and corporate image influences customer loyalty in restaurant industry of Ghana. Restaurants owners must set standards and train employees to provide steady service delivery. There should be constant communication to customers and other stakeholders through social media such as face book, whatsApp, Hi5, Imo, to mention but a few.

Managers must provide quality service: communication, reliability, courtesy credibility etc, and develop a positive image of the company through consistent service quality delivery.

\section{Limitation of the study}

The decision about the size of the sample was taken considering time and cost, the need of precision and a variety of further considerations. Due to the limit of time and costs, the population was narrowed to only one out of the ten regions in Ghana

This study was also limited to few construct, other existing construct were excluded in the study.

\section{References}

[1] Anderson, E. W., C. Fornell, et al. (1994). "Customer Satisfaction, Market Share, and Profitability: Findings from Sweden.” Journal of Marketing 58(July): 53-66.

[2] Anderson, E. W., \& Sullivan, M. W. (1993). The antecedents and consequences of customer satisfaction for firms. Mark. Sci., 12, 125-143

[3] Ball, D., Coelho, P. S., \&Vilares, M. J. (2006) Service personalization and loyalty.Journal of Services Marketing, 20: 391-403

[4] Bastos, R., Augusto, J., \& Muñoz Gallego, P.A. (2008). Pharmacies customer satisfaction and loyalty-a frame work analysis.

[5] Bell, S. J., Auh, S., \& Smalley, K. (2005) Customer relationship dynamics: Service quality and customer loyalty in the context of varying levels of customer expertise and

[6] switching costs. Journal of the Academy of Marketing Science, 33:169-183.

[7] Bauer, H. H., Falk, T., \&Hammerschmidt, M. (2006) eTransQual: Atransaction process- based approach for capturing service quality in online shopping. Journal of Business Research, 59(7):866875

[8] Carman, J.M. (1990), "Consumer perceptions of service quality: an assessment of the SERVQUAL dimensions",Journal of Retailing, Vol. 66 No. 1, pp. 33-55

[9] Cook, S. (2004). Customer Care Excellence: How to create an effective customer focus, (4th ed.).Kogan Page India.

[10] Cronin, J. J., Brady, M. K. G., and Hult. T. M. (2000). Assessing the Effects of Quality, Value, and Customer Satisfaction on Consumer Behavioral Intentions in Service Environments.Journal of Retailing, 76(2): 193-218.

[11] Drew, J. H. (1991). Service value and its measurement: local telephone service. In Suprenant, C. (Ed.), Add Value to Your Service: 6th Annual Services Marketing Proceedings, American Marketing Association, Chicago, IL

[12] Edvardsson (2005) “GURU'S VIEW, Service quality: beyond cognitive assessment Service Sweden Managing Service Quality”, 15 (2), pp. 127-131

[13] Eggert,E and Ulaga,W (2002) "Customer perceived value: a substitute for satisfaction in business markets?", Journal of Business \& Industrial Marketing, Vol. 17 Iss: 2/3, pp.107 - 118 
[14] Eskildsen, J., Kristensen, K., JØrnJuhl, H., \&Østergaard, P. (2004). The drivers of customer satisfaction and loyalty.

[15] The case of denmark 2000-2002. Total Quality Management \& Business Excellence, 15(5-6), 859868

[16] Gro“nroos, C.(2000)' Service Management and Marketing', Lexington Books, Lexington, MA

[17] Gro“nroos, C. (2001) “The Perceived Quality Concept: a mistake?” Managing Service Quality 11(3), pp. $150-152$

[18] Gruen, T.W.; Osmonbekov, T.; Czaplewski, A.J. (2006), leWOM: The Impact of Custome-toCustomer Online Know-how Exchange on Customer Value and Loyalty," Journal of Business Research, Vol. 59, no 4, p449-456

[19] Hair, J. F., Anderson, R. E., Tatham, R. L., \& Black, W. C. (2006b). Multivariate Data

[20] Analysis, (5th Ed.).Upple Saddle River, New Jersey: Prentice Hall.

[21] Johnson, M.D., Gustafsson, A., Andreassen, T.W., Lervik, L., \& Cha, J. (2001). The evolution and future of nationalcustomer satisfaction index models. Journal of economic Psychology, 22(2), 217245.

[22] Lai, F., Griffin, M., \&Babin, B.J. (2009) How quality, value, image, and satisfaction create loyalty at a Chinese telecom. Journal of Business Research, 62(10): 980-986

[23] Lin,H.H.,\&Wang,Y.S.(2006).Anexaminationofthedeterminantsofcustomerloyaltyinmobilecommerce contexts.Information\&management,43,271-282

[24] Klaus, P. G. (1985) Quality phenomenon: the conceptual understanding of quality in face-to-face service encounters", in Czepiel, J.A., Solomon,M.R. and Surprenant, C.F. (Eds), The Service Encounter, Lexington Books, Lexington, MA.

[25] Martey EM, Frempong, J (2014) the impact of perceived service quality dimensions on customer satisfaction in the airline industry in Ghana International journal of researchvol 1 No 10

[26] Nguyen, N. \& Leblanc, G. (2001). Corporate image and corporate reputation in customers' retention decisions in services. Journal of Retailing and Consumer Services, 8, 227-36.

[27] Parasuraman, A., Zeithamal, V. A., \& Berry, L. L. (1988). SERVQUAL: A multiple-item scale for measuring consumer perceptions of service quality. Journal of Retailing, 64, 12-40.

[28] Rust, Zeithaml, V., and Lemon, K., (2000) Driving Customer Equity. Boston: FreePress.

[29] Santos,J (2003) "E-service quality: a model of virtual service quality dimensions", Managing Service Quality: An International Journal, Vol. 13 Iss: 3, pp.233 - 246

[30] Schellhase, R., Hardock, P., \&Ohlwein, M. (2000). Customer satisfaction in business-to -business marketing: The caseof retail organizations and their suppliers.Journal of Business \& Industrial Marketing, 15(2/3), 106-121.

[31] Turel, O. and Serenko, A. (2006) - Satisfaction with mobile services in Canada: An empirical investigation, Telecommunications Policy 30 (2006), pp.314-331, 2006.

[32] Velimirović, D., Velimirović, M., \&Stanković, R. (2011) Role and importance of key performance indicators measurement. Serbian Journal of Management, 6(1): 63-72

[33] Wang, Y., Lo, H.P. and Yang, Y. (2004), “An integrated framework for service quality, customer value, satisfaction: evidence from china"s telecommunication industry", Information Systems Frontiers, Vol. 6 No. 4, pp. 325-40.

[34] Yi, Y., \& Gong, T. (2008) The electronic service quality model: The moderating effect of customer self-efficacy. Psychology \& Marketing, 25:587-601

[35] Zeithaml, V.A. (1988) - "Consumer perceptions of price, quality, and value: a means-end model and synthesis of evidence”, Journal of Marketing, Vol. 52, July, pp. 2-22. 
their current customers rather than attaining new ones. According to (Rust et al., 2000) customer loyalty is the basis of competitive advantage and controls company's performance

\section{Customer perceived-value}

Customer perceived-value is defined as the perception about quality, social psychology, benefit and money (Velimirović, et al., 2011) .The term perceived value can be defined as "the benefits or outcome that customers receive in relation to total costs (which include other associated cost plus the price of the paid with the purchase) or the consumers' overall evaluation of what is received relative to what is given"(Zeithaml, 1988). Also, Zeithaml (1988) study showed that customers who perceived value for their monies worth are more satisfied than customers who do not perceive value for monies worth. 